\title{
Editorial
}

\section{Sustainable Building Materials and Life Cycle Assessment}

\author{
Adriana Estokova ${ }^{1, *(1)}$ and Dagmar Samesova ${ }^{2}$
}

1 Institute of Environmental Engineering, Faculty of Civil Engineering, Technical University of Kosice, Vysokoskolska 4, 04200 Kosice, Slovakia

2 Department of Environmental Engineering, Faculty of Ecology and Environmental Sciences, Technical University in Zvolen, T. G. Masaryka 24, 96001 Zvolen, Slovakia; dsamesova@gmail.com

* Correspondence: adriana.estokova@tuke.sk; Tel.: +421-55-602-4265

Citation: Estokova, A.; Samesova, D. Sustainable Building Materials and Life Cycle Assessment. Sustainability 2021, 13, 2012. https://doi.org/ $10.3390 /$ su13042012

Received: 1 February 2021

Accepted: 1 February 2021

Published: 13 February 2021

Publisher's Note: MDPI stays neutral with regard to jurisdictional claims in published maps and institutional affiliations.

Copyright: (C) 2021 by the authors. Licensee MDPI, Basel, Switzerland. This article is an open access article distributed under the terms and conditions of the Creative Commons Attribution (CC BY) license (https:/ / creativecommons.org/licenses/by/ $4.0 /)$.
Today, sustainability principles should be applied to all industries, including the building sector, which ranks among the sectors with the most negative environmental impacts. Great emphasis should be placed on sustainable innovation in material research and technologies in close connection with climate change mitigation and the protection of natural resources. This Special Issue of the journal Sustainability collects research papers focused on the investigation of sustainability potential and environmental performance of individual building materials, materials in construction systems, and whole buildings as well.

Improving the durability of materials and thus prolonging the service life of constructions is a key sustainability element in the building sector. Briatka et al. (Contribution 1) studied the effect of the internal curing of cement-based composites on the development of changes in the volume and strength parameters in order to mitigate cracks and, thus, prolong the concrete's service life. The replacement of part of the natural aggregate by lightweight aggregate exhibited significant improvement of the parameters studied, especially in the early stage of the concrete. The results confirm the potential of lightweight aggregate to act as internal curing, especially in sealed systems, regarding to the compressive strengths.

The durability of concretes affected by water abrasion was evaluated in Contribution 2 by Bodnarova et al. The authors examined the abrasion resistance of various concrete mixtures, studying the influence of both filler and binder components. The type of aggregate and its mineralogical composition and different types of active and inert mineral additives in concrete were under consideration. Experimental findings reveal that the type of aggregate is crucial in the resistance of concrete to abrasion in the early stages of maturing. However, in a long time period, the cement matrix plays a more important role. Maturation time and the microstructure of the concrete are the most important to consider when improving the abrasion resistance.

Vaclavik et al. (Contribution 3) presented the results of the study on not only technical but also environmental parameters of concretes when evaluating their sustainability. Environmental impacts of the individual composites with the substitution of natural aggregate by slag aggregate were analyzed by the life cycle assessment (LCA) method. Substitution of natural aggregate was aimed at saving natural resources by incorporating the waste materials-slag. The authors proposed three sustainability indicators to estimate the sustainability potential of the concretes. The sustainability indicators included environmental indicators based on LCA calculation in relation to the important mechanical properties.

Life cycle assessment (LCA) method was applied also to the evaluation of building materials used in various construction systems in Contribution 4 . The authors compared the environmental impacts of three types of construction system: reinforced concrete, hot-rolled steel, and light steel constructions. The light steel construction system reached the lowest values for embodied energy and global warming potential, followed by the reinforced concrete construction and hot-rolled steel construction. In addition, the constructions were evaluated by the LEED certification system as well. 
The sustainability of building materials in whole buildings, assessed by LCA, was presented for single-family houses and apartment blocks by Ayagapin et al. (Contribution 5). The paper provides a comparison of the environmental load results connected to the cradle-to-grave phase of materials used in the residential houses in Reunion Island and France. The environmental impacts of the buildings in Reunion Island, represented by global warming potential per unit floor area, were found to be higher by more than one third than in mainland France.

Abouhamad et al. (Contribution 6) also used the life cycle assessment methodology to assess the overall environmental impacts of light steel framed buildings within its whole life cycle, including the recycling and reuse of the materials at the end of the life of the building. The light steel framed buildings exhibited much lower environmental impacts when compared to the conventional steel construction system. The global warming potential and primary energy of materials in building could be significantly reduced if taking into account the processes of material recycling and reuse.

Not only the sustainability of materials but also sustainability evaluation of the 13 family houses in Slovakia was reported in paper by Kridlova Burdova et al. (Contribution 7). The authors presented the sustainability results by the Building Environmental Assessment System (BEAS). They assessed the sustainability in several categories such as site selection and project planning; building construction; indoor environment; energy performance; water management; and waste management. The results of this study show that the residential houses do not sufficiently meet the criteria of sustainable construction.

\section{List of Contributions}

1. Briatka, P.; Makýš, P.; Gašparík, J. A Prolongation of the Service Life of Cement-Based Composites by Controlling the Development of Their Strength and Volume Changes. Sustainability 2020, 12, 8479, doi:10.3390/su12208479.

2. Bodnárová, L.; Ťažký, M.; Ťažká, L.; Hela, R.; Pikna, O.; Sitek, L. Abrasive Wear Resistance of Concrete in Connection with the Use of Crushed and Mined Aggregate, Active and Non-Active Mineral Additives, and the Use of Fibers in Concrete. Sustainability 2020, 12, 9920, doi:10.3390/su12239920.

3. Václavík, V.; Ondová, M.; Dvorský, T.; Eštoková, A.; Fabiánová, M.; Gola, L. Sustainability Potential Evaluation of Concrete with Steel Slag Aggregates by the LCA Method. Sustainability 2020, 12, 9873, doi:10.3390/su12239873.

4. Abouhamad, M.; Abu-Hamd, M. Life Cycle Assessment Framework for Embodied Environmental Impacts of Building Construction Systems. Sustainability 2021, 13, 461, doi:10.3390/su13020461.

5. Ayagapin, L.; Praene, J.P. Environmental Overcost of Single Family Houses in Insular Context: A Comparative LCA Study of Reunion Island and France. Sustainability 2020, 12, 8937, doi:10.3390/su12218937.

6. Abouhamad, M.; Abu-Hamd, M. Life Cycle Environmental Assessment of Light Steel Framed Buildings with Cement-Based Walls and Floors. Sustainability 2020, 12, 10686, doi:10.3390/su122410686.

7. Krídlová Burdová, E.; Selecká, I.; Vilčeková, S.; Burák, D.; Sedláková, A. Evaluation of Family Houses in Slovakia Using a Building Environmental Assessment System. Sustainability 2020, 12, 6524, doi:10.3390/su12166524.

Author Contributions: Conceptualization and writing: A.E.; reviewing: D.S. All authors have read and agreed to the published version of the manuscript.

Conflicts of Interest: The authors declare no conflict of interest. 